\title{
Fiscal and monetary dynamics: A policy duo for the Indonesian economy
}

\author{
E.Z.W. Yuan \& C. Nuryakin \\ Department of Economics, Faculty of Economics and Business, Universitas Indonesia, Depok, Indonesia
}

\begin{abstract}
Research on how monetary and fiscal authorities can and should interact has been abundant internationally; however, the amount of research is still small in Indonesia. One consensus that converges from the research is the importance of coordination between monetary and fiscal authorities for an optimal inflation rate and economic growth as well as to minimise welfare losses. What has not yet been observed is the optimal level of monetary and fiscal policy pertaining to monetary and fiscal policy interaction, which is the focus of this research. In a non-cooperative game theory model, we used a loss function of monetary policy, which uses the Surat Berharga Bank Indonesia (SBI) rate as its instrument, and fiscal policies with government spending as their tool, as the payoff for each authority. In general, the result shows that the actual SBI rate and government expenditure have yielded in non-Nash equilibrium and non-Pareto efficiency equilibrium. Thus, there is much room to improve the policies, especially the smoothing of government expenditure throughout the year; that is, improving government expenditure absorption in the second quarter and moderating it in the third and fourth quarters, as well as lowering SBI rates.
\end{abstract}

\section{INTRODUCTION}

A good policy mix between monetary and fiscal policies is required for an economy to experience stable economic growth along with a low and stable inflation rate. A previous study by Taylor (1994) found that high economic stability generates high economic growth and a low inflation rate in the long run. Nevertheless, there is no single market economy in which monetary and fiscal policies are governed by a single institution. Reigning over different institutions, each monetary and fiscal authority has different objectives, with the monetary authority focusing on price stability and the fiscal authority focusing on output level stability. On the other hand, as empirically witnessed and theoretically proven, there is a trade-off relationship between price and output levels; high output is often followed by high price level. Thus, a good policy mix between the two authorities heavily relates to whether or not the institutions coordinate.

Conflicting results were found in previous research on the coordination between monetary and fiscal policies. Some of these studies are from Rogoff (1985), Kydland and Prescott (1977), and Bartolomeo and Giocchino (2004). Specifically, Rogoff (1985) argues that society will be better off when the central banker agent does not share the social objective function; instead, the only concern is inflation rate stabilisation. However, Bartolomeo and Giocchino (2004) found that economic stability could not be achieved under either authority. Under monetary leadership, the central bank is not forced to bail out fiscal deficits that cannot guarantee fiscal stability, although fiscal dominance has forced the central bank to monetise public debts, which deprioritises monetary stability.

On the other hand, more recent research has discovered the opposite. Nordhaus (1994), Petit (1989), Beetsma and Bovenberg (1997), Faure (2003), and Javed and Sahinoz (2005) are some researchers who are proponents of the beneficial effect of monetary and fiscal policy coordination. Nordhaus (1994) theoretically explains that the separation of monetary and 
fiscal authority will provoke high fiscal deficit and interest rates that are too high to promote a healthy level of private investment and adequate long-term growth of potential output. Petit (1989) empirically found that the coordination between monetary and fiscal policies has a positive impact on the macroeconomic condition in Italy. Beetsma and Bovenberg (1997) also proposed the need for coordination between monetary and fiscal authorities.

Faure (2003) found that in the European Union, the coordination of monetary and fiscal policies yields a higher welfare by disciplining the government and stabilising the employment level, even if the inflation rate increases ex post. Javed and Sahinoz (2005) also found that coordination between the authorities generated a positive impact in Turkey.

Notable research on the interaction between monetary and fiscal policies in Indonesia has been implemented by Mochtar (2004), Simorangkir and Goeltom and (2012), and Santoso (2012). Santoso (2012) and Simorangkir and Goeltom (2012) found that, in the event of negative output shock, the coordination between monetary and fiscal policies in Indonesia results in fewer welfare losses than if no coordination exists. Simorangkir and Goeltom (2012) used the game theory model and empirical studies using data from 1970 to 2002, whereas Santoso (2012) used the Dynamic Stochastic General Equilibrium (DSGE). While suggesting that a coordinated policy can be strengthened through a coordinated institution, such as Dewan Moneter, Santoso (2012) also found that the policy coordination in response to inflationary shock has not been as efficient as the response to output shock in Indonesia.

Mochtar (2004) measured the quasi-fiscal activities of the central bank, which indicates the dominance of monetary authority over fiscal authority. Using a vector autoregressive estimation, Mochtar (2004) ran the data from 1998 to 2003 and found that, after the financial crisis in 1997-98, fiscal authority played a dominant role, although at a small scale. All in all, research on interactions of policies in Indonesia proves that there is coordination between monetary and fiscal policies.

Regarding optimal policy literature in Indonesia, recent research on optimal monetary policy has been conducted by Widjaja and Mardanugraha (2009), Brouver et al. (2006), Ramayandi (2007), and Kuncoro and Sebayang (2013). Ramayandi (2007) used a simple Policy Reaction Function (PRF) applied to an econometric model to predict the optimal monetary policy rates using data from 1989 to 2004 and found that, during that period, the optimal monetary policy rates were lower than the actual policy rates. Brouver et al. (2006) noted that for Indonesia the interest rates in 2005 seemed to still be higher than what the rule suggested. Kuncoro and Sebayang (2013) also argue for a generally lower optimal interest rate in the 1999-2010 period; they also used the PRF framework to predict optimal policy rates. In general, these studies argue that the monetary policy interest rates in 1989-2010 were too high.

On the other hand, Widjaja and Mardanugraha (2009) used the Guender model to predict the optimal nominal interest rate for Bank Indonesia's (BI) target of operation and found that from 2005 to 2008 the actual interest rates implemented by BI were lower than the predicted optimal policy rates. The optimal policy rates are predicted using the gap between actual inflation and the targeted inflation rate. In contrast to the findings of Brouver et al. (2006) and Kuncoro and Sebayang (2003), this research argues that the monetary policy interest rates from 2005 to 2008 were too low.

Kendrick and Amman (2011) prove theoretically that small quarterly changes in a fiscal policy provide a less volatile path for the economy than large annual changes. A quarterly instead of annual approach to evaluate a fiscal policy calls for time distribution of government expenditure. Kuncoro and Sebayang (2003) found that in Indonesia the deviation of the implemented fiscal policy from their optimal values in 1999-2010 fluctuates within a one-year period.

Despite the importance of coordination between monetary and fiscal policies, and the abundant research on an optimal policy, there is still a lack of research on the optimal policy with a comprehensive model regarding monetary and fiscal interactions. The independence of BI that was granted in 1999 and the implementation of a price targeting the framework in 2005 have changed the nature of the interaction between monetary and fiscal policies in Indonesia,which affects the optimal policy rates between the two. Thus, this research aims to find the optimum policy mix between fiscal and monetary policies by simulating certain levels of policy instruments using game theory. 


\section{THE BASIC FRAMEWORK}

The literature on coordination between monetary and fiscal policies has used the DSGE method, the mathematical approach with an additional game theory method, and empirical studies to prove the mathematical model, to determine whether coordination between monetary and fiscal authorities generates higher output. Here, output is not limited to economic output, but it also includes social welfare, inflation, and the utility level of monetary and fiscal authorities.

Our framework is based on game theory prediction for local optimal monetary and fiscal policies. The local term for optimal policy rates in this study means that we only analyse optimal strategies of each agent that are very close to the existing policy rates. This also means that we look for optimal policy rates that, if implemented, require the least drastic changes from existing policy rates.

First, we assume that BI and the Government of Indonesia (GOI) have the objective to minimise welfare losses in the following function:

$$
\begin{gathered}
L_{B I}\left(r_{i}, g_{j}\right)=\alpha_{B I}(\hat{y}-\bar{y})^{2}+\beta_{B I}(\hat{p}-\bar{p})^{2}+\gamma_{B I}(r-\bar{r})^{2} \\
L_{G O I}\left(r_{i}, g_{j}\right)=\alpha_{G O I}(\hat{y}-\bar{y})^{2}+\beta_{G O I}(\hat{p}-\bar{p})^{2}+\delta_{G O I}\left(g_{i}-\bar{g}\right)^{2},
\end{gathered}
$$

where $\mathrm{BI}$ indicates monetary authority, GOI is the fiscal authority, and $r_{i}$ and $g_{j}$ denote any level of policy instruments for both monetary and fiscal policies. The payoff function shows that even though both BI and GOI have an inflation and output element in their payoffs, the weight that the fiscal and monetary authorities attribute to final targets in terms of output and inflation differ; that is, $\alpha_{B I}<\alpha_{G O I} ; \beta_{B I}>\beta_{G O I}$. This assumption is based on the theoretical framework proposed by Dixit and Lambertini (2001) and has been used by Simorangkir and Goeltom (2012). The payoffs show the loss function of the economy, which represents the stabilisation objective of both policies. For BI, its loss function consists of deviation of the predicted price level from the optimum price level, deviation of the predicted output from the optimum output, and deviation of the real interest rate from its optimum, which is set to $2 \%$. For GOI, the loss function consists of deviation of the predicted price level from the optimum price level, deviation of the predicted output from the optimum output, and deviation of the fiscal policy, which is government expenditure $g_{j}$, from its optimum level.

Thus, the framework of the game is as follows:

Player: $N=\{B I, G O I\}$

Strategy: $S=\left\{r_{i}, g_{j}\right\}$, where $i, j>0$.

Payoff:

$$
\begin{gathered}
L_{B I}\left(r_{i}, g_{j}\right)=1(\hat{y}-\bar{y})^{2}+2(\hat{p}-\bar{p})^{2}+1(r-\bar{r})^{2} \\
L_{G O I}\left(r_{i}, g_{j}\right)=2(\hat{y}-\bar{y})^{2}+1(\hat{p}-\bar{p})^{2}+1\left(g_{i}-\bar{g}\right)^{2}
\end{gathered}
$$

The weight on output and price levels in BI and GOI $\left(\alpha_{B I}=1, \alpha_{G O I}=2, \beta_{B I}=2\right.$, and $\beta_{G O I}=1$ ) are according to Simorangkir and Goeltom (2012).

The game model used in this research is a static game of complete information. A static game has two distinct features. First, each player simultaneously and independently chooses an action. Both players, which in this research are BI and GOI, choose their action at the exact same moment. Second, the condition on the players' choices of actions and payoffs are distributed to each player. Once BI and GOI make their choices of the government expenditure level and SBI rate, their choices will result in a particular loss value from the predicted price and output level or a probabilistic distribution over the loss value. In addition to this static game, a game of complete information requires that all the players in the game have common knowledge among them in four components: (1) the possible actions of all players, (2) all the possible outcomes, (3) how each combination of actions of all players affects which outcome will materialise, and (4) the preferences of each and every player over outcomes. 


\section{EMPIRICAL MODEL}

To quantify the welfare loss in Equations 3 and 4, we estimate the output level $\left(y^{\prime}\right)$ and the price level $\left(p^{\prime}\right)$. To predict the effect of the fiscal and monetary policies (i.e. government expenditure and SBI rate) on the stability of macro economy indicators, which include the price and output levels or Gross Domestic Product (GDP), one needs to find the model best fit to predict the price and output levels. There are numerous models for predicting output and price levels. However, we used the model from Mohanty and John (2015) to predict the price level and modified models from Grossman (1988) to predict the output level. The predicted price level is the prediction when the monetary authority sets $r_{i}$ and the fiscal authority sets $g_{j}$. The predicted output level is the prediction when the fiscal authority sets $g_{j}$ and the monetary authority sets $r_{i}$. The predictions of the price and the output levels in certain policy rates used models that are estimated first using econometrics.

The fiscal theory of the price level shows how fiscal policy affects the price level, in contrast to the conventional view that inflation is always a monetary phenomenon. An aggregate supply equation and the quantity theory of money can explain how the output gap and quantity of money in the economy affects the price level, as mentioned in Mohanty and John (2015), in addition to the monetary policy measured by interest rates. Thus, the regression model for the price level is estimated in Equation 5.

$$
p_{t}=\gamma_{0}+\gamma_{1} m_{t}+\gamma_{,} o_{t}+\gamma_{3} r_{i}+\gamma_{4} g_{t}
$$

where $p_{t}$ is the consumer price index level in period $t$ (using a base year of 2002); $m_{t}$ is the quantity of money in the economy in period $t$ (in hundreds of trillions); and $o_{t}$ is the output gap of the economy in period $t$.

Equation 6 is estimated by the Ordinary Least Squares (OLS) method. The output gap is the gap between the actual output level $y_{t}$ and its potential output $\bar{y}$, which requires the calculation of $\bar{y}$. Several methods estimate the potential output as well as the output gap. Nasution and Hendranata (2014) used Indonesia's data from 1983 to 2013 and found that the best output gap measurement for Indonesia is the band pass filter, outperforming the Hodrick-Prescott filter, autoregressive integrated moving average, production function, and structural vector autoregressive estimation. For the output level, the modification models in Grossman (1988) were used, which incorporated the Solow growth model with Keynes and the neoclassical model of investment. The regression model for the output level is estimated by the two-stage leastsquares model.

$$
\begin{aligned}
& y_{t}=\beta_{0}+\beta_{1} k_{t}+\beta_{2} l_{t}+\beta_{3} g_{t}+\varepsilon_{t} \\
& k_{t}=\beta_{4}+\beta_{5} r_{t},
\end{aligned}
$$

where $y_{t}$ is the natural logarithm of GDP in period $t ; k_{t}$ is the natural logarithm of capital in period $t ; l_{t}$ is the natural logarithm of labour in period $t ; g_{t}$ is the natural logarithm of government expenditure in period $t$; and $r_{t}$ is the monetary policy rates in period $t$.

The monetary policy instrument $r$ is chosen based on which policy instrument best fits the model. Monetary policy instruments considered in this model are BI rates, Fasilitas BI rates, repurchase order rates, SBI rates, and Jakarta interbank overnight rate.

As mentioned in Equations 3 and 4, the payoffs are in the form of a loss function, which is deviation of the price level, output level, interest rate, and government expenditure from their optimum values. Optimum values of the output level, price level, and government expenditure are obtained through finding their trends, where the regression models are as follows:

$$
\begin{gathered}
y_{t}^{d}=\theta_{0}+\theta_{1} t \\
p_{t}^{d}=\delta_{0}+\delta_{1} t \\
g_{t}^{d}=\varphi_{0}+\varphi_{1} t,
\end{gathered}
$$


where $y_{t}^{d}$ is the deseasonalised data for $y$ in period $t ; p_{t}^{d}$ is the deseasonalised data for $p$ in period $t ; g_{t}^{d}$ is the deseasonalised data for $g$ in period $t$; and $t$ is the period, $t=1$ for the first quarter of 2005.

Equations 7, 8, and 9 estimate the optimum value of the output level, price level, and government expenditure for each quarter in 2014 and 2015. These equations are estimated using the OLS method.

\section{RESULTS AND ANALYSIS}

In the years 2014 and 2015, GOI was struggling to boost economic growth in order for the Indonesian economy to graduate from the 'middle income trap'. Since President Joko Widodo began his term, various economic stimulant packages were implemented to boost consumption and investment. The fiscal policies implemented were considered ambitious, owing to a 5.7\% economic growth target in 2015 (Ministry of Finance, n.d.).

On the other hand, the global crisis as a result of the global financial crisis and the aftermath of the Greek crisis forced BI to keep the benchmark interest rate (i.e. BI rate) as high as it could to prevent possible capital outflow from Indonesia. Many economists debated the stance that BI took at that time, arguing that the domestic interest rate was not a significant pulling factor of capital flow in Indonesia. Thus, lowering the domestic interest rate should help boost economic growth and achieve economic stability, without having a significant capital outflow to disrupt the balance of the economy. The policy mix that happened during 2014 and 2015 was generally represented by a loose fiscal policy but a tight monetary policy.

Figures 1 and 2 show that during 2014-15, the actual price was generally lower than the optimal price, except for the fourth quarter of 2014 when the actual price jumped against its optimal level. A sudden price increase in the fourth quarter of 2014 was related to the cut on electric subsidy by the government that was fully implemented in November 2014. There was also a global oil price increase at the end of 2014; at the same time, there was a cut on government subsidies for oil and an elimination of the subsidy on gases by the newly elected President Joko Widodo in October 2014. The cost of gasoline (premium) was raised from $R p$ 6,500

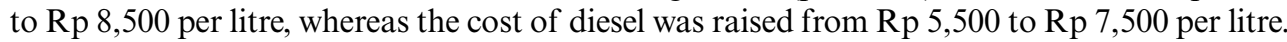

The output level has more volatility across quarters within a one-year period, which also shows the business cycle in a one-year period. The output level in the first and fourth quarters of the years 2014 and 2015 was below the optimum level, but it jumped above the optimum level in the third quarter of both years. The economic growth in 2014 and 2015 slumped relatively to 2012 levels due to weaker foreign demand, slower investment growth, and the global oil price dropping in 2015. The investment slump, especially in 2014, was due to the common investor behaviour to wait and see the performance of President Joko Widodo after the election before investing in Indonesia.

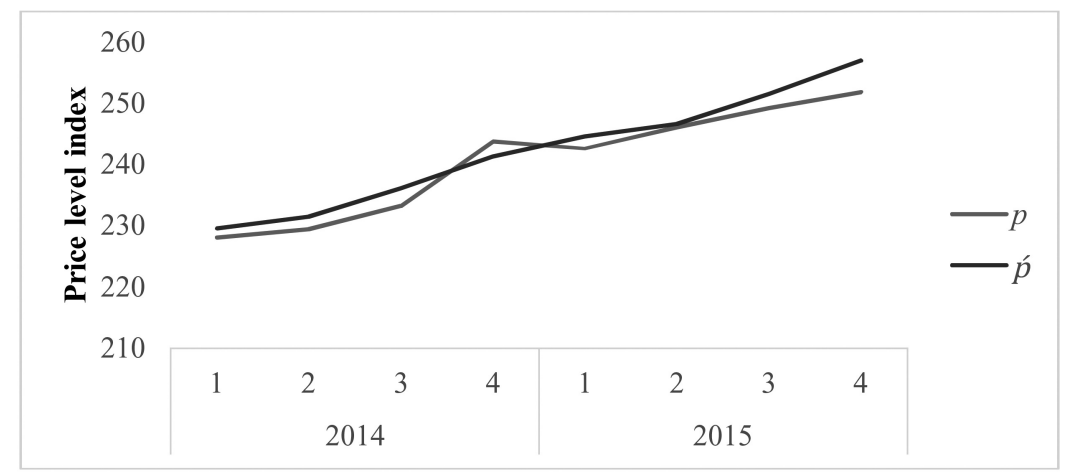

Figure 1. Actual and optimum price levels in 2014 and 2015. Source: Authors' calculation and Biro Pusat Statistik (2016). 
14.7

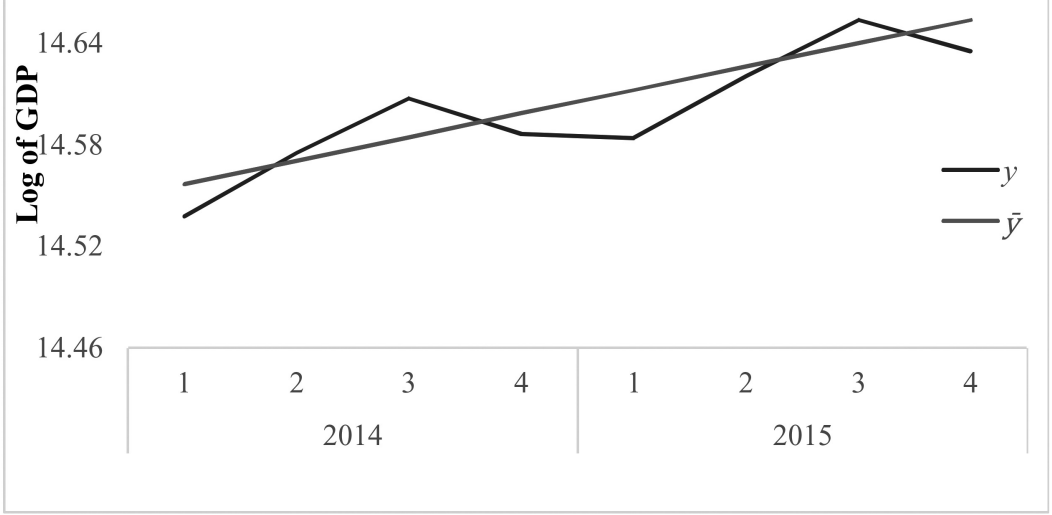

Figure 2. Actual and optimum output levels in 2014 and 2015. Source: Authors' calculation and Biro Pusat Statistik (2016).

Table 1. Regression estimation for output and price model.

Dependent variable: $Y$

Constant

\begin{tabular}{l}
\hline \\
G \\
R \\
K \\
M \\
O \\
d1 \\
d4
\end{tabular}

Adjusted R2

Probability $>$ F

BP test

BG test

VIF
(1)

\section{$12.3752^{* * * *}$}

$0.1794 * * *$

$-0.0322^{* * *}$

$$
\text { . }
$$$$
\text { . }
$$

$$
\cdot
$$$$
0.7081
$$$$
0.0000
$$

0.0000

(2)

$10.3605^{* * *}$
$0.0598^{* * *}$
$-0.1965^{* * *}$
$0.2496^{* * *}$
$\cdot$
.
0.0032
$-0.0251^{*}$
0.9735
0.0000
0.22
0.17
2.68

Dependent variable: $p$

(3)

(4)

$\begin{array}{cc}-331.217^{* *} & -132.9626^{* * *} \\ 44.0694^{* * *} & 20.5252^{* * *} \\ -4.3734 * * * & -1.3494 * * * \\ . & . \\ . & 28.4722^{* * *} \\ . & -4.6842^{* * *} \\ . & 9.423^{* * *} \\ . & -6.7367 * * \\ 0.8077 & 0.9667 \\ 0.0000 & 0.0000 \\ & 0.29 \\ & 0.12 \\ & 4.64\end{array}$

Significance level $* 10 \%, * * 5 \%, * * * 1 \%$.

"." (dots) means that the corresponding variables are not included in the regression.

BP test $=$ Breusch-Pagan Test .

BG test $=$ Breusch-Godfrey test.

VIF $=$ Variance inflation factor.

Source: Authors' calculation.

\subsection{Game simulation}

Using the model predicted by econometrics, the payoff function for monetary and fiscal authorities with each policy rate is as follows (see the regression results in Table 1):

$$
\begin{gathered}
L_{B I}\left(r_{i}, g_{j}\right)=1\left(\hat{y}\left(r_{i}, g_{j}\right)-\bar{y}(t)\right)^{2}+2\left(\hat{p}\left(r_{i}, g_{j}\right)-\bar{p}(t)\right)^{2}+1(r-\bar{r})^{2} \\
L_{G O I}\left(r_{i}, g_{j}\right)=2\left(\hat{y}\left(r_{i}, g_{j}\right)-\bar{y}(t)\right)^{2}+1\left(\hat{p}\left(r_{i}, g_{j}\right)-\bar{p}(t)\right)^{2}+1\left(g_{i}-\bar{g}(t)\right)^{2},
\end{gathered}
$$


where output and price levels are predicted for each value of $r_{i}$ and $g_{j}$, and $t=[37,44]$.

$$
\begin{gathered}
\hat{y}_{t}\left(r_{i}, g_{j}\right)=10.361+0.249 k_{t}+0.059 g_{j}-0.025 d_{4}, \\
k_{t}=14.383+0.249 r_{i} \\
\hat{p}_{t}\left(r_{i}, g_{j}\right)=-132.99+28.472 m_{t}-4.684 o_{t}-1.349 r_{i}+20.525 g_{j}+9.423 d_{1}-6.736 d_{4}
\end{gathered}
$$

Moreover, regression results for the optimum level of output, price, and government expenditure at $t$ are as follows:

$$
\begin{aligned}
& \overline{y_{t}}=14.044+0.014 t \\
& \overline{p_{t}}=121.493+2.865 t \\
& \overline{g_{t}}=11.762+0.032 t
\end{aligned}
$$

The strategy for each authority includes the policy rates (SBI rates and government expenditure level) that are possible to be implemented by either authority, based on the actual implementation for the last five years. The games are formed in a $50 \times 14$ matrix. There are 50 rows of SBI rates ranging from $4 \%$ to $8.9 \%$, with a 0.1 interval. As for the government expenditure in a form of natural logarithm, there are 14 different strategies ranging from 12.1 to 13.4 , with a 0.1 interval.

The simulation of the game shows that there are multiple Nash equilibria for each quarter. The equilibria shown in Table 2 are the local Pareto efficiency equilibrium (in italics) and

Table 2. Results of game simulation for 2014 and 2015.

\begin{tabular}{ccccccc}
\hline Quarter & & GOI & BI & LGOI & LBI & Total L \\
\hline 2014 & & & & & & \\
1 & Actual & 12.3 & 7.2 & 1.895 & 13.784 & 15.679 \\
& Nash 1 & 12.5 & 7 & 0.025 & 10.085 & 10.11 \\
2 & Nash 2 & 12.4 & 5.5 & 0.03 & 10.088 & 10.118 \\
& Actual & 12.5 & 7.1 & 4.428 & 20.389 & 24.817 \\
& Nash 1 & 12.8 & 6.9 & 0.008 & 11.586 & 11.594 \\
3 & Nash 2 & 12.7 & 5.3 & 0.01 & 11.589 & 11.599 \\
& Actual & 13.3 & 7 & 13.301 & 36.694 & 49.995 \\
& Nash 1 & 12.7 & 6.4 & 0.013 & 9.828 & 9.841 \\
4 & Nash 2 & 12.8 & 7.4 & 0.016 & 9.833 & 9.849 \\
& Actual & 13.3 & 6.9 & 4.515 & 21.829 & 26.344 \\
& Nash 1 & 12.9 & 6.5 & 0.007 & 12.838 & 12.845 \\
2015 & Nash 2 & 13 & 7.3 & 0.012 & 12.841 & 12.853 \\
1 & & & & & & \\
\multirow{2}{*}{2} & Actual & 12.5 & 6.7 & 5.972 & 22.342 & 28.314 \\
& Nash 1 & 12.5 & 6.3 & 0.074 & 10.451 & 10.525 \\
& Actual & 12.6 & 6.7 & 0.098 & 10.805 & 10.903 \\
3 & Nash 1 & 12.6 & 5.9 & 0.026 & 10.664 & 10.69 \\
& Nash 2 & 12.7 & 7.1 & 0.028 & 10.671 & 10.699 \\
& Actual & 13.4 & 6.8 & 27.514 & 66.082 & 93.596 \\
4 & Nash 1 & 12.8 & 5.4 & 0.035 & 11.105 & 11.14 \\
& Nash 2 & 12.9 & 6.9 & 0.038 & 11.108 & 11.146 \\
& Actual & 13.4 & 7.1 & 5.892 & 25.182 & 31.074 \\
& Nash 1 & 12.9 & 5.2 & 0.01 & 13.449 & 13.459 \\
& Nash 2 & 13 & 6.7 & 0.015 & 13.455 & 13.47 \\
\hline
\end{tabular}

Note: Local Pareto efficiency equilibrium represented in italics.

Note: $\mathrm{L}_{\mathrm{BI}}=$ Loss of Bank Indonesia (monetary sides).

Note: $\mathrm{L}_{\mathrm{GOI}}=$ Loss of Government of Indonesia (fiscal sides).

Source: Authors' calculation. 
the local Nash equilibrium point that is the closest to the actual policy rates. The local optimal point, in opposition to the global optimal point, is the solution that is optimal within a neighbouring set of candidate solutions. On the other hand, the global optimum point is the optimal solution among all possible solutions (Floudas et al., 2013). Theoretically, the actual SBI rates and the government expenditure level should be one of the Nash equilibria in the same period if each player acts independently and rationally, without coordination at all. Nevertheless, the simulation in 2014 and 2015 does not find any period that has a Nash equilibrium point equal to both monetary and fiscal policies implemented. The Pareto efficiency between monetary and fiscal policies can be attained when both authorities coordinate optimally (Dixit, 2001).

Graphic representation of Table 2 is shown in Figures 3 and 4. Figure 3 shows the actual SBI rate, its closest Nash equilibrium, and the Pareto efficiency equilibrium in 2014-15. The Nash equilibria move close to their actual levels, with a maximum deviation of $0.4 \%$; these have a $0.3 \%$ average difference with the actual rates.

Figure 4 shows the actual government expenditure level, its Nash equilibrium level, and the Pareto efficiency level in 2014-15. In contrast to the monetary sides, there are relatively large

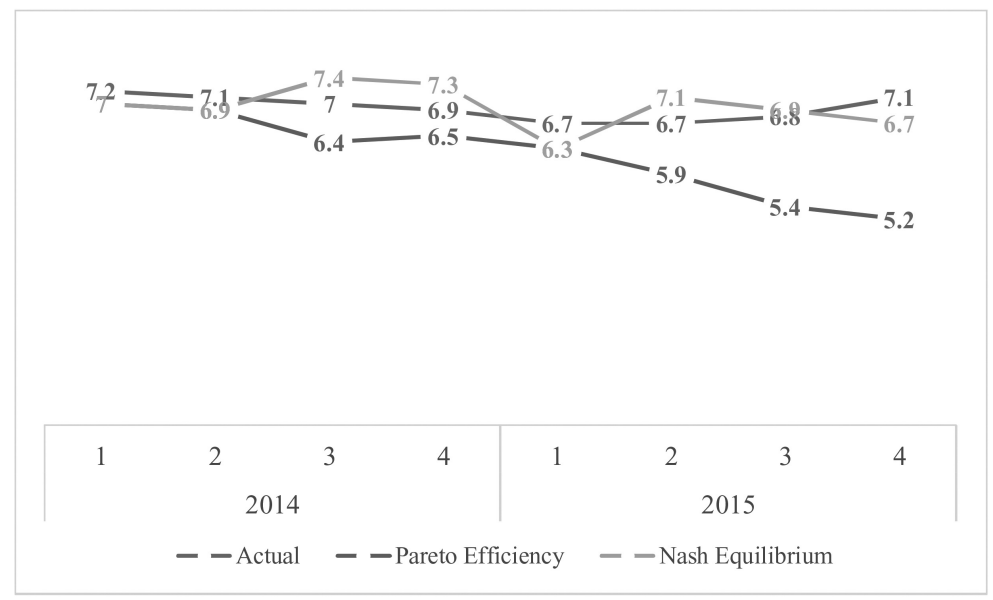

Figure 3. Actual equilibrium, Nash equilibrium, and Pareto efficiency of SBI in 2014 and 2015. Source: Authors' calculation.

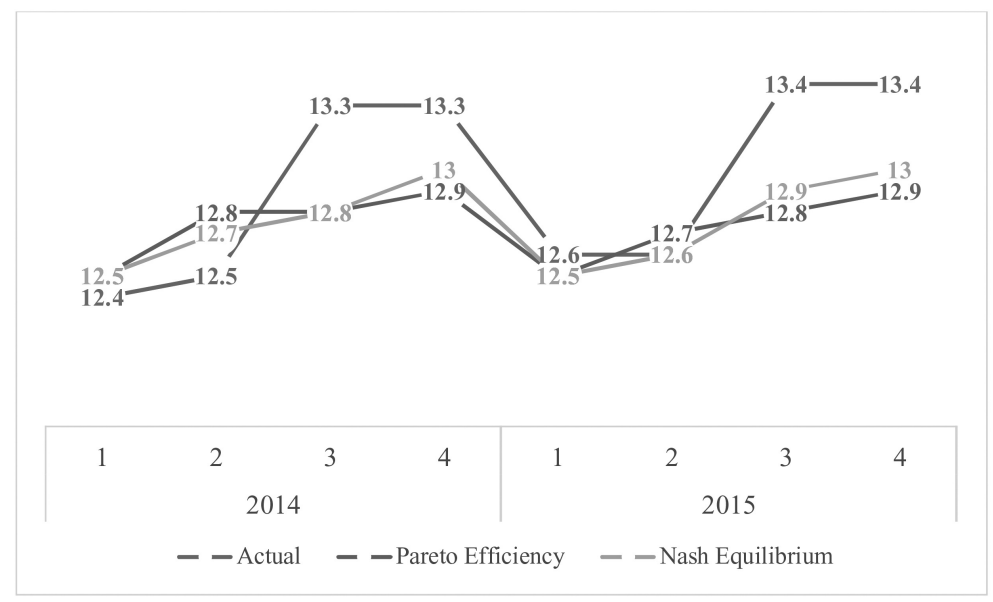

Figure 4. Actual equilibrium, Nash equilibrium, and Pareto efficiency of the government expenditure level in 2014 and 2015. Source: Authors' calculation. 
differences between the actual government expenditure levels and even the closest Nash equilibrium level, with the exception of the first and second quarters of 2015. On average, deviation of the actual government expenditure from the closest Nash equilibrium is Rp 900 trillion.

Deviation of the actual level of policy rates from its Nash equilibrium policy rates may be caused by several possible factors. First, BI and/or GOI may implement policies not based on stabilisation, which is represented by a loss function, but they only aim for low inflation or high economic growth. Second, there may be a modelling error, which means the weight of each price and output level stabilisation might not be captured by a coefficient as suggested in this study; that is, 2 for output growth and 1 for price level in the GOI loss function, and 1 for output growth and 2 for price level in the BI loss function. Third, the game theory model used in this study (i.e. the non-cooperative single game) assumes that there is common knowledge and symmetric information. However, asymmetric information may have occurred between GOI and $\mathrm{BI}$ regarding the economic condition that may affect the loss function between the two, leading to the result of the policies deviating from the true Nash equilibrium. Finally, a possible cause is that in real life there are other factors, such as socio-political factors, that are involved in fiscal and monetary policymaking. For example, the fiscal authority does not act rationally in response to the monetary authority, which may be caused by the rigidity of the national budget planned almost one year ahead. The business cycle within one year forces government expenditure to follow the economic cycle. The government is also often forced to accelerate the absorption of the government budget in the third and fourth quarters to spend the budget.

The Pareto efficiency of SBI rates generally shows that the optimum point of SBI rates falls below the actual level in 2014 and 2015. This implies that SBI rates implemented in 2014 and 2015 were too high for the economy to stabilise. Even though the Pareto efficiency of SBI rates in 2014 and 2015 shows a decreasing trend, in the fourth quarter of 2014, optimum SBI rates increased from $6.3 \%$ to $6.4 \%$. This may have happened because of the sudden jump in the price level in the fourth quarter of 2014 that was caused by the increase in global oil prices and the withdrawal of electric and oil government subsidies.

Lower optimum SBI rates may be because the actual price levels in 2014 and 2015, except for the fourth quarter of 2014, were still lower than their optimum levels, leaving some room for lower SBI rates. This may also be caused by the optimum level of government expenditure that is also generally lower than its actual level; thus, high SBI rates are not needed to stabilise the economy.

The Pareto efficiency of government expenditure levels has made visible patterns. The first and second quarters of 2014 and 2015 have actual government expenditures below the optimum level, whereas the third and fourth quarters of both years have actual government expenditure levels above the optimum level. This means that there should be redistribution of government expenditure throughout quarters within one year, which proves the Taylor theory of fiscal policy in the study by Kendrick and Amman (2011).

Figure 5 shows that the predicted inflation is proved to be more stable than the actual inflation, if GOI and BI apply the optimal policy rates. Even though the actual inflation was lower than the predicted inflation when the policies were optimal in the third quarter of 2014 and fourth quarter of 2015, the actual inflation in the first, second, and fourth quarters of 2014 and the first, second, and third quarters of 2015 was higher than the inflation predicted in the optimal policy rates. For example, the actual inflation in the fourth quarter of 2014 became as high as $8.96 \%$, but if GOI and BI had coordinated optimally and implemented the Pareto efficiency, the inflation would have only gone to $4.82 \%$.

On the other hand, the Pareto efficiency is predicted to have higher output growth than the actual output growth. Figure 6 shows that in the first quarter of 2014 the actual output growth was $4.04 \%$ and in the third quarter it hit $5.53 \%$, whereas the stabilisation policies yielded as high as $5.95 \%$ in the first quarter of 2014 and $5.76 \%$ in the third quarter of 2014 . The optimal policy rates yield higher output growth.

In general, stabilisation of the economy in 2014 and 2015 required time redistribution of government expenditure, lower level of government expenditure in the annual total, and lower SBI rates. With the implementation of optimal policy rates, the output growth is predicted to 


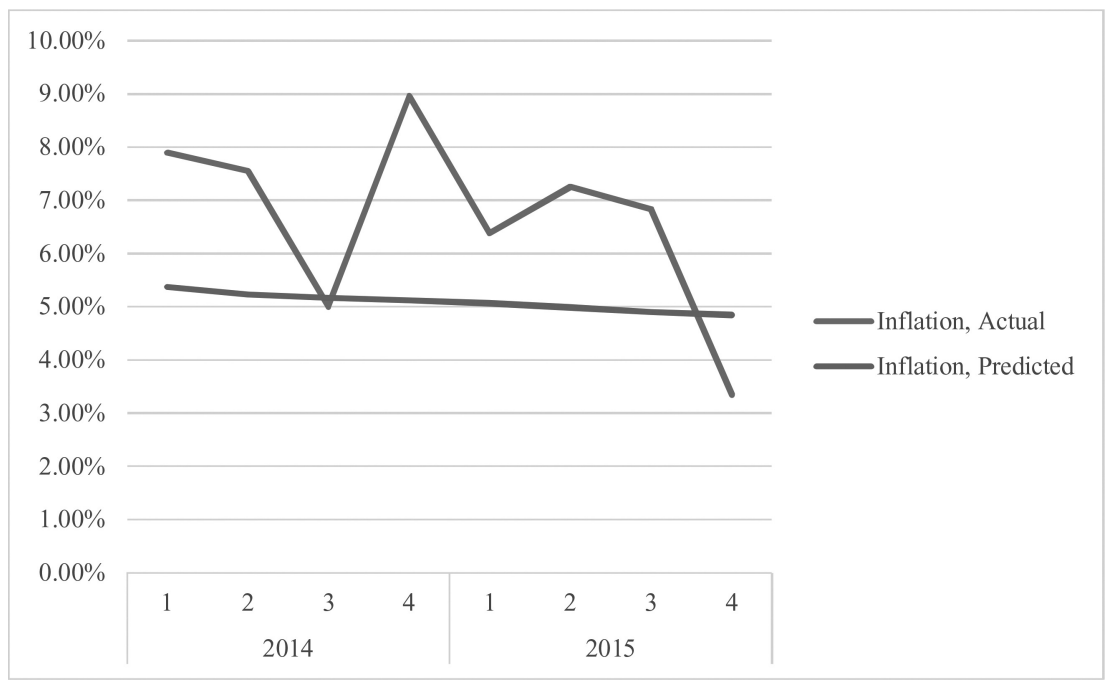

Figure 5. Actual and predicted inflation for optimal policy rates. Source: Authors' calculation.

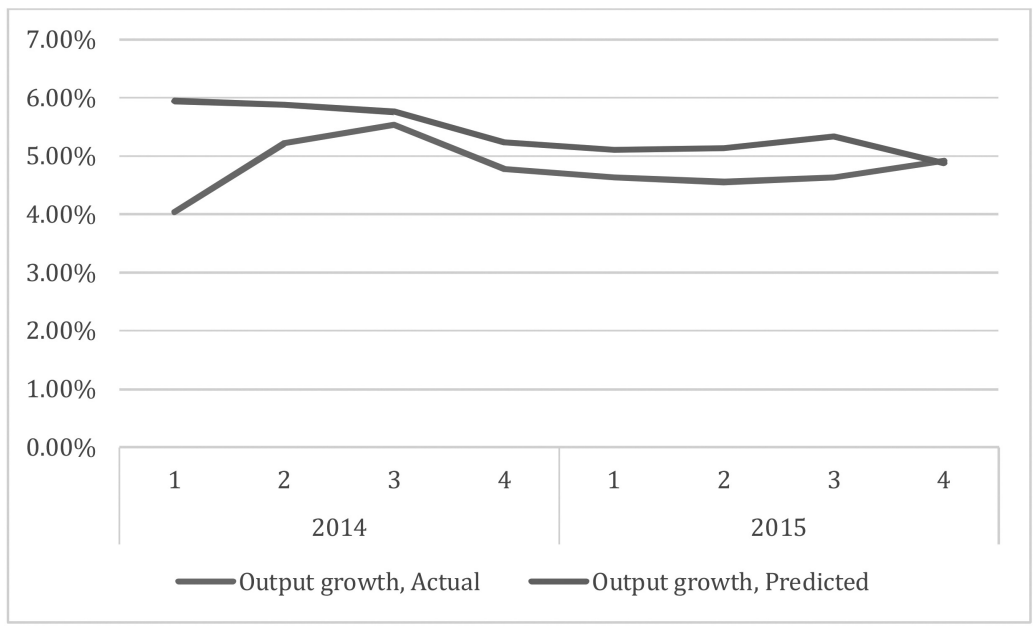

Figure 6. Actual and predicted output growth for optimal policy rates. Source: Authors' calculation.

be higher than the actual growth, but inflation rates are predicted to be more stable and lower than the actual inflation rates.

\section{CONCLUSIONS}

Policy coordination between monetary and fiscal authorities has been the object of many studies in Indonesia. Whereas a monetary policy aims for low and stable inflation, a fiscal policy aims for output growth and low unemployment. The difference in their objectives has become increasingly apparent since the independence of BI in 1999.

Although earlier research argued that coordination between monetary and fiscal policies has a negative impact on social welfare, more recent research, especially in Indonesia, has 
proved that coordination between policies lessens the social welfare loss. Furthermore, in search for optimal policy rates in Indonesia, previous research used a modified econometric model to estimate the optimality of either fiscal or monetary policy. The present research finds the optimal policy rates for both fiscal and monetary authorities using the game theory model approach to capture the interaction between monetary (BI) and fiscal (GOI) authorities.

Using a loss function to depict economic stabilisation, the game simulates the economic condition if monetary and fiscal authorities take different policy actions in the period 2014 Q1-2015 Q4 and analyses the actual policies taken (i.e. the Nash equilibrium and the Pareto efficiency).

There are generally slight differences between the actual SBI rates, the monetary policy, and their Nash equilibrium, whereas the differences in the fiscal policy are wider. Deviation of the actual monetary and fiscal policy rates from their Nash equilibrium might be caused by factors such as the objective of BI and GOI not being stable, but rather the output and price levels; the modelling error, especially the weighting of the objectives; asymmetric information between BI and GOI; and socio-political factors that exogenously affect the decision of the authorities.

While the simulation shows the importance of coordination between the two authorities, the Pareto efficiency shows that, in order to stabilise the economy in 2014 and 2015, SBI rates had to be lower and government expenditure had to be redistributed throughout the year. GOI must implement time distribution of government expenditure to smooth the output and price levels in the economy. The simulation predicts higher output growth and lower inflation rate in the implementation of optimal policy rates.

Some caveats in this research include the assumptions constructed in the model of loss function, in that exogenous factors, such as the socio-political and business cycle factors, cannot be captured in the model, which also causes deviation between the actual and Nash equilibrium of the policies. There are also differences in the time frame between the monetary and fiscal authorities taking action; while BI decides on interest rates every month, GOI plans the national budget almost one year ahead; thus, its implementation is greatly affected by the plan.

The game theory model in this research used a simultaneous single game. Yet, there is still the need to use a repeated game model or a sequential (or dynamic) game model between monetary and fiscal authorities. Further research is suggested to use the dynamic game model, based on the Saulo et al. (2013) theoretical framework.

\section{REFERENCES}

Bartolomeo, G.D. \& Giocchino, D.D. (2004). Fiscal-monetary policy coordination and debt management: A two stage dynamic analysis. Universita Degli Studi di Roma 'La Sapienza' Working Paper 74.

Beetsma, R.M.W.J. \& Bovenberg, A.L. (1997). Central bank independence and public debt policy. Journal of Economic Dynamics and Control, 21(4-5), 873-894.

Biro Pusat Statistik (2016). Available at www.bps.go.id

Brouver, G.D., Ramayandi, A. \& Turvey, D. (2006). Macroeconomic linkages and regional monetary cooperation: Steps ahead.Asian Economic Policy Review, I(2), 284-301.

Dixit, A. \& Lambertini, L. (2001). Monetary-fiscal policy interactions and commitment versus discretion in a monetary union. European Economic Review, 45(4-6), 977-987. doi:10.1016/ S0014-2921(01)00134-9.

Faure, P. (2003). Monetary and fiscal policy fames and effects of institutional differences between the European Union and the rest of the world. Revue economique, 937-959.

Floudas, C.A., Pardalos, P.M., Adjiman, C., Esposito, W.R., Gümüs, Z.H., Harding, S.T., Klepeis, J.L., Meyer, C.A. \& Schweiger, C.A. (2013). Handbook of test problems in local and global optimization, vol. 33. New York: Springer Science \& Business Media.

Goeltom, M.S. (2007). Monetary and fiscal policy synergy in Indonesia. In M.S. Goeltom (Ed.), Essays in macroeconomic policy: The Indonesian experience (pp. 106-123). Jakarta: PT Gramedia Pustaka Utama.

Grossman, P. (1988). "Growth in Government and Economic Growth: the Australian Experience." Australian Economics Papers 27: 33-45.

Javed, Z.H. \& Sahinoz, A. (2005). Interaction of monetary and fiscal policy in case of Turkey. Journal of Applied Sciences, 5(2), 220-226. 
Kendrick, D.A. \& Amman, H.M. (2011). A Taylor rule for fiscal policy. Tjalling C. Koopmans Research Institute Discussion Paper 11-17.

Kuncoro, H. \& Sebayang, K.A.D. (2013). The dynamic interaction between monetary and fiscal policies in Indonesia. Romanian Journal of Fiscal Policy IV, 4(1), 47-66.

Kydland, F.E. \& Prescott, E.C. (1977). Rules rather than discretion: The inconsistency of optimal plans. The Journal of Political Economy, 85(3), 473-492.

Ministry of Finance (n.d.). Available at: www.kemenkeu.go.id. Accessed 29 June 2016, 05.10 WIB.

Mochtar, F. (2004). Fiscal and monetary policy interaction: Evidences and implication for inflation targeting in Indonesia. Working Paper Bank Indonesia (Penerbit Kanisius), 111-140.

Mohanty, D. \& John, J. (2015). Determinants of inflation in India. Journal of Asian Economics, 36, 86-96.

Nasution, D. \& Hendranata, A. (2014). Estimasi output gap Indonesia (Estimation of Output Gap in Indonesia). Jakarta: Badan kebijakan Fiskal, Kementerian Keuangan Republik Indonesia.

Nordhaus, W. (1994). 'Policy games: Coordination and independence in monetary and fiscal policies.' Brookings Papers on Economic Activity, 5(2), 139-216.

Petit, M.L. (1989). Fiscal and monetary policy coordination: A differential game approach. Journal of Applied Econometrics, 4(2).

Ramayandi, A. (2007). Approximating monetary policy: Case study for the ASEAN-5. Working Papers in Economics and Development Studies.

Rogoff, K. (1985). The Optimal Degree of Commitment to an Intermediate Monetary Target. Quarterly Journal of Economics, 100, 1169-1190.

Santoso, W. (2012). Interaksi Kebijakan Moneter dan Fiskal di Indonesia. (Interaction of Monetary and Fiscal Policy in Indonesia) In Sri Adiningsih (Ed.), Koordinasi dan Interaksi Kebijakan FiskalMoneter: Tantangan ke Depan (Coordination and Interaction of Fiscal-Monetary Policy: Future Challenges) (pp. 225-262). Yogyakarta: Penerbit Kanisius.

Saulo, H., Dos, S.B., Rêgo, L.C. \& Divin, J.A. (2013). Fiscal and monetary policy interactions: A game theory approach. Annals of Operations Research, 206(1), 341-366.

Simorangkir, I. \& Goeltom, M.S. (2012). Peranan Koordinasi Kebijakan Moneter dan Fiskal terhadap Perekonomian Indonesia. (Roles of Monetary and Fiscal Policy Coordination in Indonesian Economy) In Sri Adiningsih (Ed.), Koordinasi dan Interaksi Kebijakan Fiskal-Moneter: Tantangan ke Depan (Coordination and Interaction of Fiscal-Monetary Policy: Future Challenges) (pp. 83-110). Yogyakarta: Penerbit Kanisius.

Taylor, J.B. (1994). Stabilization policy and long-term economic growth. Paper presented at the Center for Economic Policy Research Conference.

Widjaja, M. \& Mardanugraha, E. (2009). The optimal instrument rule of Indonesia monetary policy. International Journal of Economic Policy Studies, 55-75. 